\title{
Mixed fractals and anisotropy in subantarctic marine macroalgae from South Georgia: implications for epifaunal biomass and abundance
}

\author{
J. Davenport ${ }^{1, *}$, P. J. A. Pugh ${ }^{2}$, J. McKechnie ${ }^{1}$ \\ ${ }^{1}$ University Marine Biological Station Millport, Isle of Cumbrae, Scotland KA28 0EG, United Kingdom \\ ${ }^{2}$ British Antarctic Survey, High Cross, Madingley, Cambridge CB3 0ET, United Kingdom
}

\begin{abstract}
Fractal dimensions $(D)$ of image perimeters of 4 macroalgae (Macrocystis pyrifera, Desmarestia menziesii, Schizoseris condensata, Palmaria georgica) collected at South Georgia, Southern Ocean were established over a wide scale range. For 3 species ( $M$. pynfera, S. condensata, P. georgica) cross-frond $D$ was also estimated. At large scale all species showed complex perimeters $(D 1.26$ to 1.83 , depending on species), but showed reduced complexity (low D) at small scale, and so have mixed fractal characteristics. Cross-frond $D$ was low in the 3 species studied, indicating anisotropy, and was markedly low in P. georgica which has extensive, smooth, flat fronds. Epifaunal community analysis demonstrated that epifaunal abundance and biomass were related more to the scale at which complexity occurs than degree of complexity itself. S. condensata and $D$. menziesii (particularly complex, high $D$ ) show high eplfaunal abundance and biomass and a predominance of large animals, $M$. pyrifera and $P$ georgica (simpler, lower $D$ ) have low abundances and biomasses and the epifauna is dominated by small animals. $M$. pyrifera is fairly complex (D ca 1.3 ) at scales above $50 \mathrm{~mm}$ its complexity will impinge on fish, birds and mammals, not epifauna. M. pyrifera beds have a perimeter $D(c a 1.4)$ similar to those of convoluted coastlines.
\end{abstract}

KEY WORDS: Mixed fractals - Anisotropy $\cdot$ Macroalgae $\cdot$ Epifauna

\section{INTRODUCTION}

The first scientific application of fractal dimension (D) was that of Mandlebrot (1967), using the geographical data of Richardson (1961) Mandlebrot demonstrated that, if one attempted to measure the length of a coastline by using dividers and a map, the length depended upon the 'step length' setting of the dividers; the smaller the step length, the longer the measured coastline. The relative complexity of the perimeter of a 2-dimensional structure can be described by its fractal dimension $(D)$. $D$ can most easily be estimated by plotting ('Richardson plot') step length $(X)$ against number of steps needed to 'walk' the perimeter $[N(X)]$ on double logarithmic log paper (Mark 1984). This results in a straight line of slope $-D$.

·E-mail: j.davenport@udcf.gla.ac.uk
$D$ ranges between 1 (perfectly Euclidian differentiable line) and 2 (completely self-similar line, complex at all scales, non-differentiable). In ecological systems measurement of $D$ allows formal estimate of a habitat's physical complexity over a wide range of scales. Early applications included estimates of coral reef fractal dimension (Bradbury \& Reichelt 1983, Bradbury et al. 1984, Mark 1984) and the relationship between bald eagle nesting frequency and coastline complexity (Pennycuik \& Kline 1986). The major ecological application of fractal geometry has centred on the links between plant fractal geometry and associated faunal community structure (e.g. Morse et al. 1985, Lawton 1986, Shorrocks et al. 1991, Gunnarsson 1992, Gee \& Warwick 1994 a b). In general terms, such studies have shown an association between high fractal dimensions of vegetation and greater diversity of animal community (e.g. Gee \& Warwick 1994a), and/or greater relative abundance of smaller animals (Morse et al. 1985 . 
Shorrocks et al. 1991. Gunnarsson 1992, Gee \& Warwick 1994b).

Measurement of $D$ not only describes self-similarity of structure over many spatial scales, but may also identify scales where distinct changes in complexity occur (Mandlebrot 1977, Burrough 1981). Structures characterized by different $D$ values at different scale ranges are described as 'mixed fractals' (Russ 1994). Investigations on plants have largely ignored mixed fractals, but concentrated instead on comparing similarly sized plants with different growth forms (different $D$ ), at similar scales, though a lower $D$ at smaller scales was identified in several species by Gee \& Warwick (1994a).

Measurement of true surface fractal dimension of objects is difficult and measuring techniques currently rely heavily on assessment of boundary complexity of 2-dimensional images extracted from 3-dimensional objects (Russ 1994). Thus measured, $D$ is a good estimate of overall complexity if an object is isotropic, i.e. similarly complex in 3 dimensions as in 2 , but not if it is anisotropic, i.e. its complexity in the third dimension is different from that in the other two.

Samples of near-shore brown (Phaeophyceae) and red (Rhodophyceae) subtidal algae of a great range of sizes and growth forms were collected from the subantarctic island of South Georgia $\left(54-55^{\circ} \mathrm{S} ; 36-38^{\circ} \mathrm{W}\right)$. South Georgia offers a pristine environment, where encrusting, colonial epifaunal forms (which would complicate measurement of epifaunal abundance/biomass of algae) are rare on the fronds of algae.

Subtidal algae were studied, rather than intertidal species, for 2 reasons. Firstly, intertidal macroalgae tend to collapse when emersed, thus altering effective complexity. Secondly, sampling of littoral epifauna at low water may bias samples in favour of small, physiologically tolerant animals that remain in contact with the emersed macroalgae. Larger or less tolerant animals might only exploit immersed algae and migrate to submerged habitats on the ebb tide. The studies conducted so far that have involved consideration of macroalgal fractal dimension and epifaunal community characteristics (Gee \& Warwick 1994a, b) were conducted on intertidal plants sampled during emersion.

The primary objective of the study was to test the following hypotheses: (1) That macroalgae have smooth, simple surfaces (and low $D$ ) at smaller scales. (2) That the abundance and biomass of epifauna associated with macroalgae are controlled by the scale(s) at which complexity (and high $D$ ) emerges, as well as by the complexity itself.

Because fronds of some macroalgal species appear to be smooth and flat to the naked eye, yet have complex perimeters, the second objective of the study was to test the hypothesis: (3) That algae with flat fronds would be anisotropic and therefore have lower epifaunal abundances and biomasses than species with complexity in 3 dimensions, even if measured $D$ values were comparable.

This last hypothesis may appear trivial, or even tautological, but no previous study of fractals and vegetation appears to have dealt with it, though the freshwater study of Jeffries (1993) includes an elegant attempt to measure 3-dimensional weed fractal dimension.

\section{METHODS}

Four species of macroalgae were collected at Husvik Harbour $\left(54^{\circ} 11^{\prime} \mathrm{S}, 36^{\circ} 40^{\prime} \mathrm{W}\right.$ on the sheltered north-east coast of South Georgia) on 11 and 12 March 1994 Collection sites were wave-sheltered and ca $4 \mathrm{~km}$ from the open ocean. For distribution of species see John et al. (1994). Images of all 4 species are shown in Fig. 1.

Macrocystis pyrifera (L.) C. Aghardh (Phaeophyceae). The largest marine alga in the world (Womersley 1954). Each plant consists of a number of single cylindrical stipes (ca 4-5 $\mathrm{mm}$ diameter, <60 m long) attached to a complex, basket-like holdfast. Long $(<0.5 \mathrm{~m})$, flat, pointed fronds $(0.29 \pm 0.05 \mathrm{~mm}$ thickness) and small gas bladders (pneumatocysts) are attached to the stipe at regular intervals. Beds of $M$. pyrifera extend for 50 to $200 \mathrm{~m}$ offshore at Husvik (cf. $1000 \mathrm{~m}$ in the Falklands, Strange 1992). Hereafter referred to as Macrocystis.

Desmarestia menziesii J. Aghardh (Phaeophyceae). Forms branched, bush-like thickets up to $1 \mathrm{~m}$ high. The stipe has an elliptical section (ca $3.5-5 \mathrm{~mm}$ diameter), and is dichotomously branched 4 to 5 times (first branches $2.5 \mathrm{~mm}$ thick, second $1.1 \mathrm{~mm}$, third $0.6 \mathrm{~mm}$, fourth $0.4 \mathrm{~mm}$, with tips of fronds $0.25-0.35 \mathrm{~mm}$ thick). Hereafter referred to as Desmarestia.

Schizoseris condensata (Reinsch) R. W. Ricker (Rhodophyceae). A complex red alga which, when immersed, appears bushy, conical and $<0.3 \mathrm{~m}$ high. A dense array of tiny elliptical/circular fronds $(2-4 \mathrm{~mm}$ long, $0.034 \pm$ $0.001 \mathrm{~mm}$ thick) are attached to a repeatedly branched stipe. Hereafter referred to as Schizoseris.

Palmaria georgica (Reinsch) R. W. Ricker (Rhodophyceae). This species has no stipe; the extremely smooth, flat fronds $(0.12 \pm 0.01 \mathrm{~mm}$ thick) have irregular margins, while the thallus is gradually attenuated towards the basal attachment disc. Hereafter referred to as Palmaria.

Collection of algae and images for measurement of fractal dimensions. There were separate collections for fractal and epifaunal analyses, since removal of epifauna damages plants. Three specimens each of Des- 


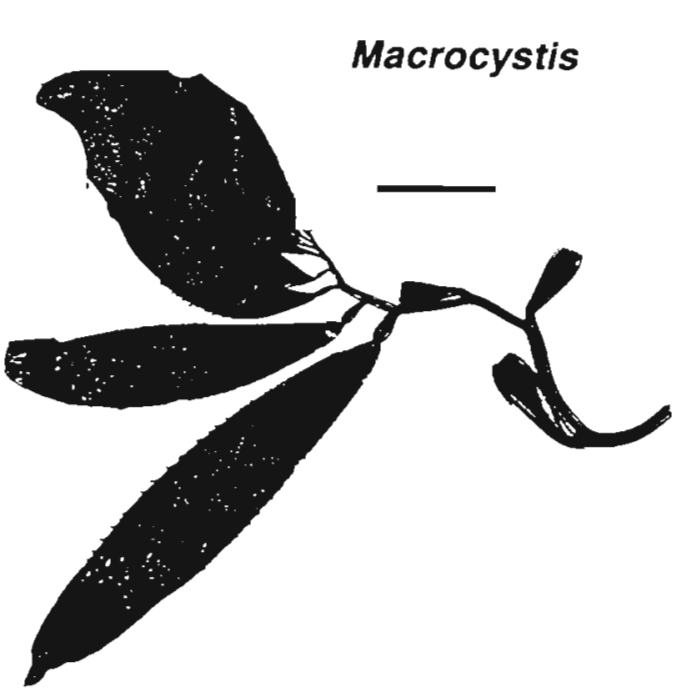

Palmaria

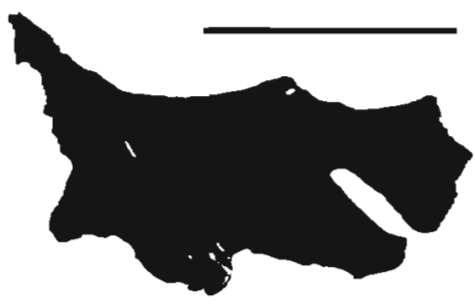

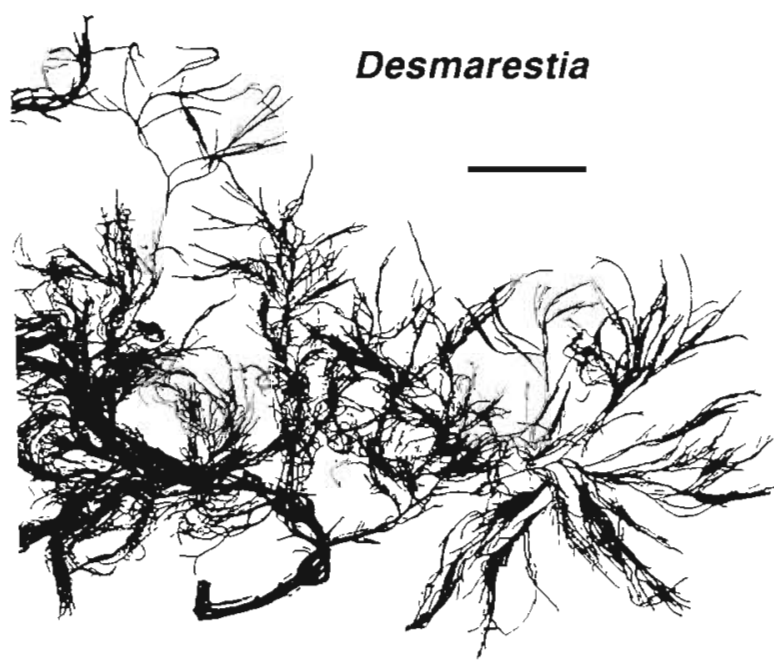

Schizoseris

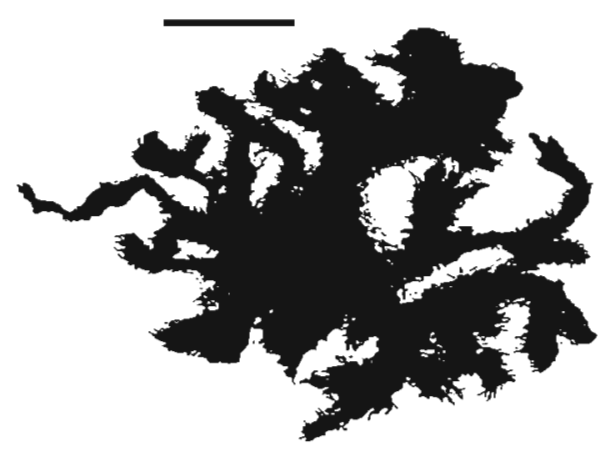

Fig. 1. Photocopied images of parts of the 4 macroalgae studied (to illustrate growth forms). All scale bars $=50 \mathrm{~mm}$. Macrocystis pyrifera: the terminal part of a plant showing the terminal blade in the process of splitting, plus pneumatophores. Desmarestia menziesii: a small part of a single plant. Palmaria georgica: a young frond (older fronds tend to have more complex margins). Schizoseris condensata: a whole plant

marestia, Schizoseris and Palmaria were collected and placed in $2 \%$ sea water-formalin until analysed in the U.K. For Macrocystis a more complex procedure was adopted where 3 whole plants (ca 25, 12.5 and $9 \mathrm{~kg}$ individual weight) were collected by wading and snorkelling to remove the holdfast from the substratum. Each, in turn, was laid out with minimal overlapping of blades on flat ground and photographed from a platform $6 \mathrm{~m}$ high, using a $10 \mathrm{~m}$ tape to provide a scale. A sequence of eight $35 \mathrm{~mm}$ colour transparencies was taken (50 $\mathrm{mm}$ lens) to yield a montage of the whole plant. Next, 3 photographs of randomly chosen parts of the plants were taken in the same manner against a $1 \mathrm{~m}$ measure with an 80-200 mm lens. Finally, with a macro lens, 3 randomly chosen parts of weed were photographed with a $50 \mathrm{~mm}$ macro lens so that a full frame occupied $0.1 \mathrm{~m}$. Randomly chosen blades of each plant (complete with pneumatocyst and piece of stipe) were preserved in $2 \%$ sea water-formalin and returned to the U.K. Vertical military aerial photographs (taken by $152 \mathrm{~mm}$ lens from a height of about $3000 \mathrm{~m}$ ) of Husvik Harbour yielded images of whole Macrocystis beds.

Two-dimensional images for estimate of perimeter $D$ were obtained from each plant (or part of plant) by combinations of direct photocopying of plant material (using both enlarging and shrinking as appropriate), microscope/camera lucida drawings of plant pieces or projected $35 \mathrm{~mm}$ slides in the case of whole/part Macrocystis plants. Precise magnifications were chosen pragmatically, depending on the plant species studied.

Perimeter $D$ for each plant image at each magnification was measured by the 'walking dividers' method (Mandlebrot 1967) and construction of a Richardson plot, following Russ (1994). A total of 5 replicate perimeter measurements, started from different ran- 
domly selected points, were made from each magnification; and, for a given image, at least 5 points in the straight line region of the Richardson plot for each of 3 plants of each species were regressed to calculate $D$.

For Macrocystis, Schizoseris and Palmaria, crossfrond $D$ was calculated from 3 fronds of each species cut transversely with a metal ruler and sharp scalpel. Profile images of the cut edges were obtained by photocopying, photomicrography and scanning electron microscopy (the last after air-drying and goldcoating) as appropriate to the scale investigated. $D$ was subsequently estimated by dividers and Richardson plot as described above. Cross-frond measurements of $D$ for Desmarestia were inappropriate because its twig-like fronds have a circular/elliptical cross section and so would yield spuriously high $D$ values (Mandlebrot 1967).

Assessment of epifaunal samples. To prevent loss of mobile epifauna, samples of macroalgae for epifaunal analysis were collected in the following manner. Whole plants, or individual stipes of Macrocystis, were each encased under water by a polythene bag sufficiently large to enclose the whole plant sample without disturbance of the mobile epifauna. Portions of 3 Macrocystis stipes as well as complete Desmarestia (3 plants), Schizoseris (5) and Palmaria (4) were collected in this fashion.

Macrocystis stipes, because of their size, had to be treated in a different fashion from the rest of the material. These were removed (in their polythene bags) from the shore, and fronds of each sample were progressively broken off and scrubbed into a bucket of sea water to remove all epifauna. The resulting suspension was filtered through a $125 \mu \mathrm{m}$ bronze mesh screen from which any material (fauna or debris) was collected and retained for sorting. It should be noted that $125 \mu \mathrm{m}$ was not the effective pore size of the bronze mesh; Macrocystis continually exudes viscous slime, especially when cut. Pilot trials showed that the slime totally blocked a $64 \mu \mathrm{m}$ sieve, and water flow was slow even with the $125 \mu \mathrm{m}$ screen. Each holding bag was washed out onto the same screen and any material collected. Extracted faunal samples were fixed in $2 \%$ sea water-formalin for $3 \mathrm{~d}$, washed in fresh water, filtered through a dual $2 \mathrm{~mm} / 125 \mu \mathrm{m}$ set of screens and the fauna picked off, counted and fixed in $5 \%$ sea waterformalin for transportation to the U.K. The pieces of each stipe were blotted dry, bundled and weighed on a Salter spring balance (accuracy $\pm 10 \mathrm{~g}$ ) and discarded.

For all. of the other macroalgae collected, each plant, complete with any fauna in its surrounding polythene bag, was placed in a bucket of $2 \%$ sea water-formalin and agitated for 5 min to detach most mobile animals. After $3 \mathrm{~d}$ in fixative all epifauna was picked off the algae and sieved and sorted as described for Macro- cystis. Each plant was blotted dry and weighed (accuracy $\pm 0.01 \mathrm{~g}$ ).

On return to the U.K., all epifaunal samples were identified as far as possible and numbers and/or biomass established for each taxon. If there were less than 30 animals in a given taxon, the maximum linear dimension ('length') of each was measured via a microscope and eyepiece graticule, and mean, minimum and maximum lengths established. Where more than 50 animals per taxon were collected, a random subsample of 30 were measured to yield a mean length. but the whole sample was inspected for the largest and smallest animals.

\section{RESULTS}

\section{Fractal dimensions}

All 4 algal species show low values of perimeter $D$ at small step lengths, but the scale at which this occurs varies a great deal amongst the species (Table 1). These

Table 1 Fractal dimensions $(D)$ of perimeters of images of 4 macroalgae measured over various scales

\begin{tabular}{|c|c|c|c|}
\hline Macroalgae & $\begin{array}{l}\text { Step length } \\
\text { range (m) }\end{array}$ & $\begin{array}{c}\text { Mean } \\
\text { perimeter }(D)\end{array}$ & $\mathrm{SD}$ \\
\hline $\begin{array}{l}\text { Macrocystis pyrifera } \\
\text { (bed outlines) }\end{array}$ & $\begin{array}{c}250-400 \\
100-250 \\
50-100 \\
25-50\end{array}$ & $\begin{array}{l}1.42 \\
1.33 \\
1.36 \\
1.18\end{array}$ & $\begin{array}{l}0.14 \\
0.05 \\
0.02 \\
0.03\end{array}$ \\
\hline $\begin{array}{l}\text { Macrocystis pyrifera } \\
\text { (individual plants) }\end{array}$ & $\begin{array}{c}0.1-1.0 \\
0.05-0.1 \\
0.02-0.05 \\
0.001-0.02\end{array}$ & $\begin{array}{l}1.26 \\
1.30 \\
1.04 \\
1.00\end{array}$ & $\begin{array}{l}0.04 \\
0.03 \\
0.00 \\
0.00\end{array}$ \\
\hline $\begin{array}{l}\text { Desmarestia menziesii } \\
\text { (individual plants) }\end{array}$ & $\begin{array}{c}0.03-0.08 \\
0.01-0.03 \\
0.005-0.01 \\
0.001-0.005 \\
0.0001-0.001\end{array}$ & $\begin{array}{l}1.83 \\
1.51 \\
1.26 \\
1.08 \\
1.00\end{array}$ & $\begin{array}{l}0.10 \\
0.01 \\
0.01 \\
0.00 \\
0.00\end{array}$ \\
\hline $\begin{array}{l}\text { Schizoseris condensata } \\
\text { (individual plants) }\end{array}$ & $\begin{array}{c}0.01-0.05 \\
0.005-0.01 \\
0.001-0.005 \\
0.0002-0.001 \\
0.00005-0.0002\end{array}$ & $\begin{array}{l}1.56 \\
1.34 \\
1.31 \\
1.05 \\
1.04\end{array}$ & $\begin{array}{l}0.07 \\
0.02 \\
0.00 \\
0.00 \\
0.00\end{array}$ \\
\hline $\begin{array}{l}\text { Palmaria georgica } \\
\text { (individual plants) }\end{array}$ & $\begin{array}{c}0.05-01 \\
0.01-0.05 \\
0.0025-0.01 \\
0.001-0.0025 \\
0.0001-0.001\end{array}$ & $\begin{array}{l}1.37 \\
1.41 \\
1.17 \\
1.13 \\
1.00\end{array}$ & $\begin{array}{l}0.02 \\
0.02 \\
0.01 \\
0.01 \\
0.00\end{array}$ \\
\hline
\end{tabular}


data show that it is by no means easy to identify relative complexity amongst the algal species from perimeter $D$. Visual comparison suggests that complexity is in the following sequence: Palmaria < Macrocystis < Desmarestia < Schizoseris. Although Desmarestia and Schizoseris do show the highest $D$ values (1.83 and 1.56 respectively), such values are only recorded for a limited part of the whole step length range.

The $D$ values for Macrocystis beds in the step length range $25-50 \mathrm{~m}$ are similar to the values recorded for single plants in the range $0.1-1 \mathrm{~m}$, but at greater step lengths, particularly $250-400 \mathrm{~m}, D$ is slightly higher (ca 1.4).

Cross-frond $D$ for 3 of the seaweed species (Table 2) shows that all of the fronds had extremely smooth surfaces, with only Schizoseris exhibiting a degree of complexity $(D=1.1)$ at very small step lengths $(1-10 \mu \mathrm{m})$ caused by hair-like processes (Fig. 2). A comparison of perimeter and cross-frond $D$ for the 3 species at common step lengths (Table 3) shows that individual fronds of Schizoseris and Palmaria with smooth surfaces, but complex margins, are highly anisotropic. In contrast, Macrocystis fronds with similarly smooth surfaces and perimeters are isotropic

\section{Epifaunal analysis}

The abundance and biomass data collected for the 4 species of seaweed (Table 4) indicate that Macrocystis supports the lowest abundance and biomass, Palmaria supports (visually, though not to a statistically significant extent) higher levels, Desmarestia has about 10 times as much biomass of epifauna per unit plant mass as Macrocystis, while Schizoseris has about 45 times the epifaunal abundance and 405 times the epifaunal

Table 2. Cross-frond fractal dimensions (D) of 3 macroalgae measured over various scales

\begin{tabular}{|c|c|c|c|}
\hline Macroalgae & $\begin{array}{l}\text { Step length } \\
\text { range (m) }\end{array}$ & $\begin{array}{l}\text { Mean cross- } \\
\text { frond } D\end{array}$ & $\mathrm{SD}$ \\
\hline \multicolumn{4}{|c|}{ Macrocystis pyrifera } \\
\hline & $0.02-0.05$ & 1.00 & 0.01 \\
\hline & $0.001-0.02$ & 1.00 & 0.00 \\
\hline & $0.00025-0.001$ & 1.03 & 0.01 \\
\hline & $0.0001-0.00025$ & 1.00 & 0.00 \\
\hline & $0.00005-0.0001$ & 1.04 & 0.00 \\
\hline & $0.000001-0.00005$ & 1.00 & 0.00 \\
\hline \multicolumn{4}{|c|}{ Schizoseris condensata } \\
\hline & $0.00001-0.01$ & 1.00 & 0.00 \\
\hline & $0.000001-0.00001$ & 1.10 & 0.00 \\
\hline \multicolumn{4}{|c|}{ Palmaria georgica } \\
\hline & $0.00001-0.1$ & 1.00 & 0.00 \\
\hline & $0.000001-0.00001$ & 1.01 & 0.00 \\
\hline
\end{tabular}
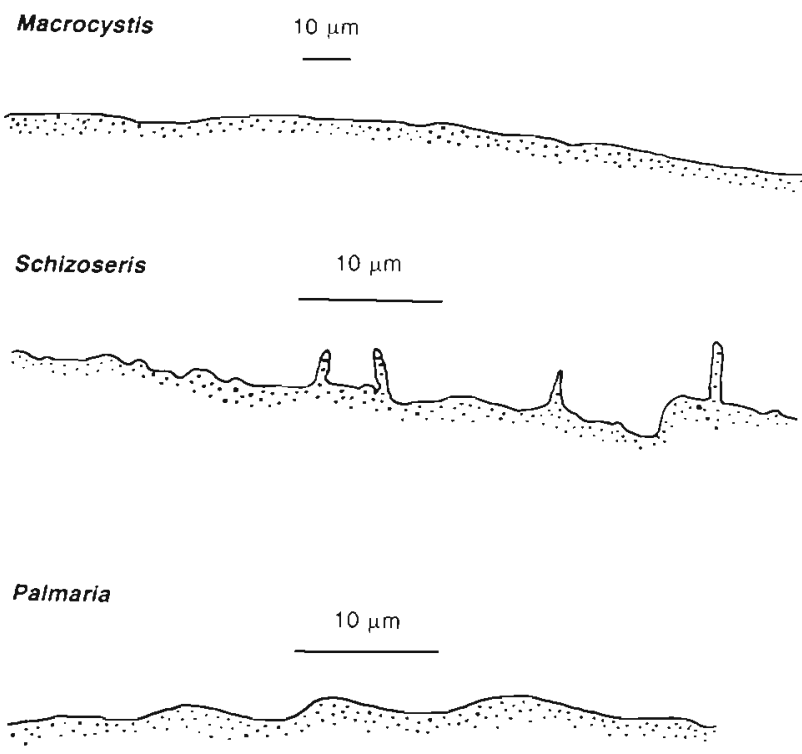

Fig. 2. Images forming the basis of profile (= cross frond) $D$ determinations (at small step sizes) in Macrocystis pyrifera, Schizoseris condensata and Palmaria georgica. These were traced from scanning electron microscope photographs of cut sections of fronds. At the high magnification required, only 1. surface of the frond was visible, but no differences between frond surfaces were detected. Note the hair-like processes (about $5 \mu \mathrm{m}$ high) on the surface of fronds of $S$. condensata

biomass of Macrocystis. The epifaunal biomass of Schizoseris is remarkably high, nearly half that of the supporting plant material.

Breaking down the epifauna of each macroalgal species (Tables 5 to 8 ) shows that on Macrocystis, 95\% of the faunal abundance (and 12\% of the biomass) was com-

Table 3. Comparison of perimeter and cross-frond fractal dimensions (D) of 3 macroalgae measured over various scales

\begin{tabular}{|c|c|c|c|}
\hline Macroalgae & $\begin{array}{l}\text { Step length } \\
\text { range (m) }\end{array}$ & $\begin{array}{c}\text { Mean } \\
\text { perimeter } D\end{array}$ & $\begin{array}{c}\text { Mean cross- } \\
\text { frond } D\end{array}$ \\
\hline \multicolumn{4}{|c|}{ Macrocystis pyrifera } \\
\hline & $0.02-0.05$ & 1.04 & 1.00 \\
\hline & $0.001-0.02$ & 1.00 & 1.00 \\
\hline \multicolumn{4}{|c|}{ Schizoseris condensata } \\
\hline & $0.005-0.01$ & 1.34 & 1.00 \\
\hline & $0.001-0.005$ & 1.31 & 1.00 \\
\hline & $0.0002-0.001$ & 1.05 & 1.00 \\
\hline & $0.00005-0.0002$ & 1.04 & 1.00 \\
\hline \multicolumn{4}{|c|}{ Palmaria georgica } \\
\hline & $0.05-0.1$ & 1.37 & 1.00 \\
\hline & $0.01-0.05$ & 1.41 & 1.00 \\
\hline & $0.0025-0.01$ & 1.17 & 1.00 \\
\hline & $0.001-0.0025$ & 1.13 & 1.00 \\
\hline & $0.0001-0.001$ & 1.00 & 1.00 \\
\hline
\end{tabular}


Table 4. Overall abundance and biomass (SD shown in parentheses) of epifauna of individual plants of 4 macroalgae. $\mathrm{n}$ is number of samples

\begin{tabular}{|c|c|c|c|}
\hline Macroalgae & $\begin{array}{l}\text { Plant mass } \\
\text { (g) }\end{array}$ & $\begin{array}{l}\text { Mear animal } \\
\text { no. } \mathrm{g}^{-1} \text { plant } \\
\text { mass }\end{array}$ & $\begin{array}{c}\text { Mean animal } \\
\text { mass }(g) g^{-1} \\
\text { plant mass }\end{array}$ \\
\hline \multicolumn{4}{|c|}{ Macrocystis pyrifera } \\
\hline$(n=3)$ & $\begin{array}{c}1880 \\
1180 \\
930\end{array}$ & $\begin{array}{c}1.303 \\
(0.795)\end{array}$ & $\begin{array}{c}0.0012 \\
(0.0006)\end{array}$ \\
\hline \multicolumn{4}{|c|}{ Desmarestia menziesii } \\
\hline$(\mathrm{n}=3)$ & $\begin{array}{c}275.3 \\
156.6 \\
57.2\end{array}$ & $\begin{array}{c}9.838 \\
(5.609)\end{array}$ & $\begin{array}{c}0.1169 \\
(0.0311)\end{array}$ \\
\hline \multicolumn{4}{|c|}{ Schizoseris condensata } \\
\hline$(\mathrm{n}=5)$ & $\begin{array}{l}45.7 \\
35.5 \\
11.0 \\
13.5 \\
21.3\end{array}$ & $\begin{array}{c}59.096 \\
(11.694)\end{array}$ & $\begin{array}{c}0.4856 \\
(0.0521)\end{array}$ \\
\hline \multicolumn{4}{|c|}{ Palmaria georgica } \\
\hline$(\mathrm{n}=4)$ & $\begin{array}{c}23.0 \\
8.0 \\
6.8 \\
8.7\end{array}$ & $\begin{array}{c}2.515 \\
(1.398)\end{array}$ & $\begin{array}{c}0.0075 \\
(0.0067)\end{array}$ \\
\hline
\end{tabular}

prised of harpacticoid copepods, though half of the biomass (but only $1 \%$ of the abundance) consisted of isopods (Serolis sp.). Appreciable quantities of the amphipod Orchomene zschaui and the bivalve Gaimardia trapesina made up most of the rest of the biomass. For Desmarestia, harpacticoid copepods made up a much smaller proportion of both abundance (about $30 \%$ ) and biomass $(0.04 \%)$; amphipods [ca $90 \%$ Orchomene zschaui, with a few (ca 5\%) Jassa sp. and unidentified lysianassoids] and isopods (all Cassidonopsis emarginata) made up nearly $60 \%$ of the numbers and over $97 \%$ of the biomass. If the 2 brown algae are compared, it is evident that the more complex species (in terms of qualitative appearance and perimeter $D$ ) has a greater abundance of larger animals, not of smaller animals as predicted from investigations on terrestrial plants.

The red algae showed similar results. Schizoseris epifauna was dominated by amphipods $185 \%$ Orchomene zschaui, 10\% Jassa sp., $5 \%$ unidentified lysianassoids) and bivalves (all Lissarca miliaris) which together made up $86 \%$ of the numbers and $98 \%$ of the biomass, while the smaller harpacticoids made up less than $12 \%$ of the numbers and only $0.02 \%$ of the biomass. In contrast, the epifauna of Palmaria included a high proportion of harpacticoids ( $41 \%$ of numbers) as well as appreciable numbers of amphipods (all $O$. zschaul) and gastropods (all littorinids).

\section{Relationship of fractal dimension and epifaunal composition}

The relationships between plant fractal dimension and abundance and biomass plotted against weighted mean length of each taxon are shown in Figs. 3 to 6. For Macrocystis (Fig. 3), all of the sampled epifauna had lengths below the step length at which complexity arises, and so they would 'perceive' the algal surface as smooth and Euclidean. For Desmarestia (Fig. 4) many of the smaller animals (harpacticoids, ostracods and mites) would similarly perceive the weed surface as smooth, but the animais which made up the bulk of the biomass (isopods and amphipods) had lengths corresponding to scales at which the algal perimeter $D$ ranged from about 1.1 to 1.3. For Schizoseris (Fig. 5), most (about $90 \%$ of abundance and $99 \%$ of biomass) had animal lengths corresponding to step lengths at which perimeter $D$ was about 1.3 , so would perceive the surface as complex. Palmaria (Fig. 6) showed a pattern with most of the smaller animals living in a Euclidean 'realm', the remainder having body lengths corresponding to step lengths at which the Palmaria perimeter $D$ was between 1.13 and 1.17.

No discernible pattern was evident amongst the algal species in terms of distribution of minimum or maximum size of those epifaunal species (e.g. Orchomene zschaui) that were common to all.

Table 5. Breakdown of epifauna associated with Macrocystis pyrifera. Numbers and biomass are summed for all of the samples analysed; mean lengths of animals are weighted for their abundances in different samples

\begin{tabular}{|lrcccc|}
\hline Epifauna & $\begin{array}{c}\text { Total } \\
\text { no. }\end{array}$ & $\begin{array}{c}\text { Total } \\
\text { biomass } \\
(\mathrm{g})\end{array}$ & $\begin{array}{c}\text { Weighted } \\
\text { mean length } \\
(\mathrm{mm})\end{array}$ & $\begin{array}{c}\text { No. as \% } \\
\text { total no. }\end{array}$ & $\begin{array}{c}\text { Biomass } \\
\text { as \% total } \\
\text { biomass }\end{array}$ \\
\hline Stauromedusae & 1 & 0.016 & 6.30 & 0.02 & 0.30 \\
Flatworms & 38 & 0.129 & 2.70 & 0.78 & 2.41 \\
Nematodes & 1 & 0.001 & 1.80 & 0.02 & 0.01 \\
Errant polychaetes & 8 & 0.033 & 4.44 & 0.17 & 0.62 \\
Spirorbis digitus & 34 & 0.029 & 1.06 & 0.70 & 0.55 \\
Gastropods & 40 & 0.100 & 1.41 & 0.82 & 1.88 \\
Bivalves & 21 & 0.607 & 5.38 & 0.43 & 11.37 \\
Harpacticoids & 4600 & 0.631 & 1.06 & 94.94 & 11.82 \\
Isopods & 54 & 2.733 & 7.79 & 1.11 & 51.22 \\
Amphipods & 48 & 1.057 & 8.06 & 0.99 & 19.82 \\
\hline
\end{tabular}




\section{DISCUSSION}

A high $D$ in a macroalga will promote energy capture per unit tissue volume by increasing the effective surface area for $\mathrm{CO}_{2}$ uptake and increasing the number of photosynthetically active cells per unit mass, but self-shading will counteract this advantage. Macroalgae would therefore be expected to show less complexity at smaller scales. It would also be predicted that self-shading will become a problem sooner for large plants (thicker fronds, greater depth range of individual plants). The results support hypothesis 1 in that all 4 algal species showed extremely smooth perimeters ( $D$ close to 1 ) at low step lengths. Macroalgal surfaces are 'mixed fractals' (Russ 1994), and it is therefore inappropriate to describe the complexity of a particular species by a single value of $D$. In general terms, the large, thickbladed Macrocystis becomes smooth in terms of perimeter $D$ (reaches the 'Euclidean domain') at scales smaller than $50 \mathrm{~mm}$, Desmarestia below $5 \mathrm{~mm}$, and Palmaria below $1 \mathrm{~mm}$. Schizoseris, a relatively small plant with very thin, translucent fronds, shows a degree of complexity at all scales, though $D$ is at relatively low levels (ca 1.05) at step lengths $<1 \mathrm{~mm}$

The data also support hypothesis 3 (which would not apply to Desmarestia because it does not have flat fronds); the other 3 species have fronds with flat surfaces (cross-frond profile $D=1$ ) at scales where measurements of perimeter $D$ indicate complexity (Table 3), thus flat algal fronds with complex margins are, as predicted, anisotropic. The significance of this in terms of low epifaunal abundance and biomass is particularly evident in the case of Palmaria, which has extremely smooth fronds, the profile $D$ being indistinguishable from 1 at step lengths up to $100 \mathrm{~mm}$.

This leaves hypothesis 2 , which concerns the relationship between epifaunal abundance/biomass and complexity of algal surfaces. It is suggested that increased fractal dimension affects epifauna in 2 ways.
Table 6. Breakdown of epifauna associated with Desmarestia menziesii. Numbers and biomass are summed for all of the samples analysed; mean lengths of animals are weighted for their abundances in different samples

\begin{tabular}{|lrcccc|}
\hline Epifauna & $\begin{array}{c}\text { Total } \\
\text { no. }\end{array}$ & $\begin{array}{c}\text { Total } \\
\text { biomass } \\
(\mathrm{g})\end{array}$ & $\begin{array}{c}\text { Weighted } \\
\text { mean length } \\
(\mathrm{mm})\end{array}$ & $\begin{array}{c}\text { No. as \% } \\
\text { total no. }\end{array}$ & $\begin{array}{c}\text { Biomass } \\
\text { as \% total } \\
\text { biomass }\end{array}$ \\
\hline Stauromedusae & 1 & 0.017 & 6.75 & 0.03 & 0.03 \\
Polychaetes & 10 & 0.269 & 11.67 & 0.27 & 0.52 \\
Gastropods & 225 & 0.516 & 1.75 & 6.10 & 1.00 \\
Bivalves & 29 & 0.480 & 3.34 & 0.79 & 0.93 \\
Harpacticoids & 1102 & 0.020 & 0.79 & 29.86 & 0.04 \\
Ostracods & 149 & 0.034 & 0.77 & 4.04 & 0.07 \\
Isopods & 940 & 21.861 & 5.44 & 25.47 & 42.47 \\
Amphipods & 1225 & 28.272 & 9.56 & 33.19 & 54.93 \\
Mites & 10 & 0.003 & 0.82 & 0.27 & 0.01 \\
\hline
\end{tabular}

Table 7. Breakdown of epifauna associated with Schizoseris condensata. Numbers and biomass are summed for all of the samples analysed; mean lengths of animals are weighted for their abundances in different samples

\begin{tabular}{|lrrcrc|}
\hline Epifauna & $\begin{array}{c}\text { Total } \\
\text { no. }\end{array}$ & $\begin{array}{c}\text { Total } \\
\text { biomass } \\
(\mathrm{g})\end{array}$ & $\begin{array}{c}\text { Weighted } \\
\text { mean length } \\
(\mathrm{mm})\end{array}$ & $\begin{array}{c}\text { No. as } \% \\
\text { total no. }\end{array}$ & $\begin{array}{c}\text { Biomass } \\
\text { as } \% \text { total } \\
\text { biomass }\end{array}$ \\
\hline Polychaetes & 5 & 0.003 & 4.22 & 0.07 & 0.01 \\
Gastropods & 151 & 1.035 & 2.93 & 2.11 & 1.63 \\
Bivalves & 1748 & 22.358 & 3.68 & 24.43 & 35.11 \\
Harpacticoids & 825 & 0.013 & 0.67 & 11.53 & 0.02 \\
Isopods & 3 & 0.014 & 2.90 & 0.04 & 0.02 \\
Amphipods & 4417 & 40.258 & 4.38 & 61.73 & 63.22 \\
Mites & 6 & 0.001 & 0.79 & 0.08 & 0.00 \\
\hline
\end{tabular}

Table 8. Breakdown of epifauna associated with Palmaria georgica. Numbers

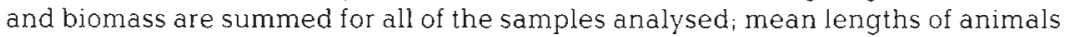
are weighted for their abundances in different samples

\begin{tabular}{|lrccrc|}
\hline Epifauna & $\begin{array}{c}\text { Total } \\
\text { no. }\end{array}$ & $\begin{array}{c}\text { Total } \\
\text { biomass } \\
\text { (g) }\end{array}$ & $\begin{array}{c}\text { Weighted } \\
\text { mean length } \\
(\mathrm{mm})\end{array}$ & $\begin{array}{c}\text { No. as \% } \\
\text { total no. }\end{array}$ & $\begin{array}{c}\text { Biomass } \\
\text { as \% total } \\
\text { biomass }\end{array}$ \\
\hline Polychaetes & 5 & 0.011 & 4.38 & 4.20 & 1.55 \\
Gastropods & 13 & 0.091 & 2.43 & 10.92 & 12.94 \\
Bivalves & 1 & 0.029 & 4.95 & 0.84 & 4.10 \\
Harpacticoids & 49 & 0.006 & 0.83 & 41.18 & 0.81 \\
Ostracods & 6 & 0.000 & 0.65 & 5.04 & 0.06 \\
Isopods & 3 & 0.050 & 7.20 & 2.52 & 7.12 \\
Amphipods & 38 & 0.517 & 7.27 & 31.93 & 73.40 \\
Unidentified eggs & 4 & 0.000 & 0.41 & 3.36 & 0.03 \\
& & & & &
\end{tabular}

First, any complexity (perimeter $D>1$ ), at any scale, will increase the area of smooth surfaces (profile $D=1$ ) available for colonization by animals small enough to 'perceive' the surface as smooth and therefore live in a 'Euclidean domain'. In making this statement we are aware that our understanding of substratum surface perception in weed-dwelling invertebrates is poor; we assume that visual analysis of the complexity of the 

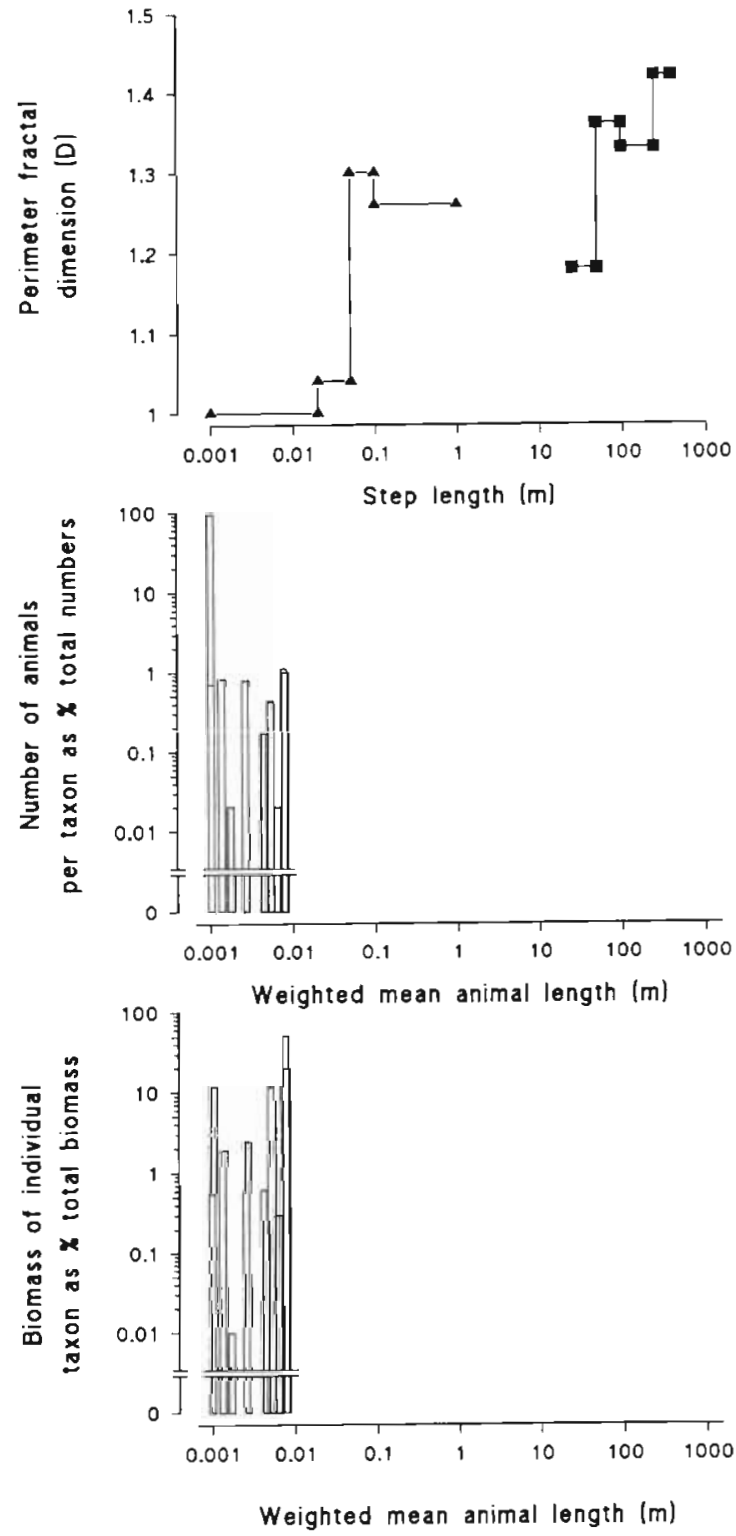

Fig. 3. Macrocystis pyrifera. Relationship between perimeter fractal dimension (D) of plants measured at varıous scales (step lengths) in relation to epifaunal abundance and biomass. Each taxon is represented by a single histogram block. $D$ for individual plants: $\Delta-\wedge ; D$ for kelp bed outlines:

environment is limited, and that tactile stimuli. (which may only be collected from the vicinity of the animal concerned) are most important. It is probable that all animals will perceive structure at scales less than their body length, but such 'finer' discrimination would not influence the analysis presented here. However, the extent of 'coarser' discrimination at scales substantially above body length is much less easy to predict; in our analysis we assume it to be limited. Second, increased fractal dimension will affect those larger animals which 'perceive' the surface as complex ('fractal
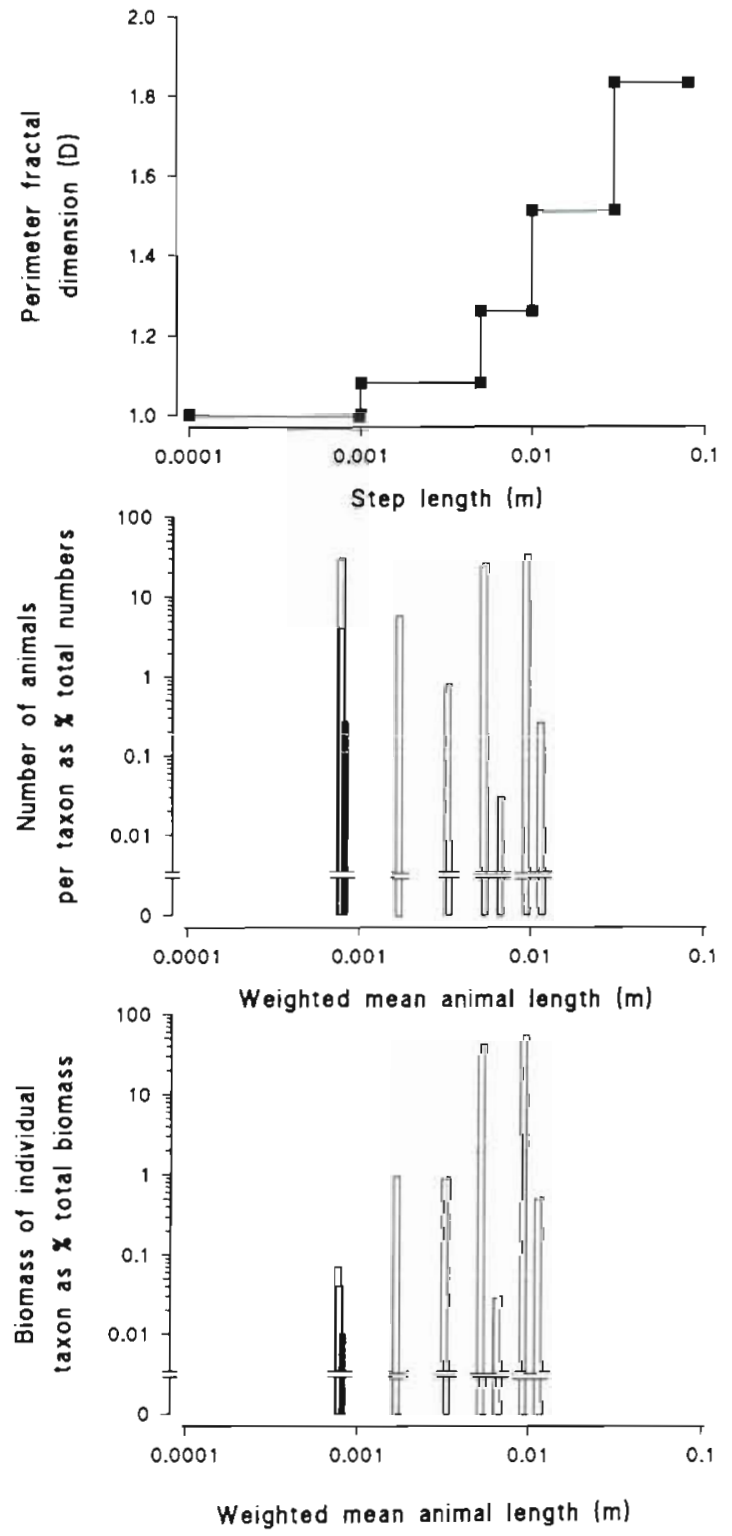

Fig. 4. Desmarestia menziesii. Relationship between perimeter $D$ of plants measured at various scales (step lengths) in relation to epifaunal abundance and biomass. Each taxon is represented by a single histogram block

domain'] by offering greater 'fractal extent' [a concept intermediate between area and volume; see Pennycuick (1992) for discussion] for feeding, attachment or refuge. The balance between these 2 effects on abundance and biomass of epifauna will depend on the scale at which complexity emerges, the degree of complexity (value of $D$ ), and the size range of potential colonizing animals. It perhaps also depends upon the relative mobility of potential colonizers; highly mobile organisms may perceive the substratum as complex even if they are small in relation to the scale of complexity (assuming adequate visual capacity and 3 - 

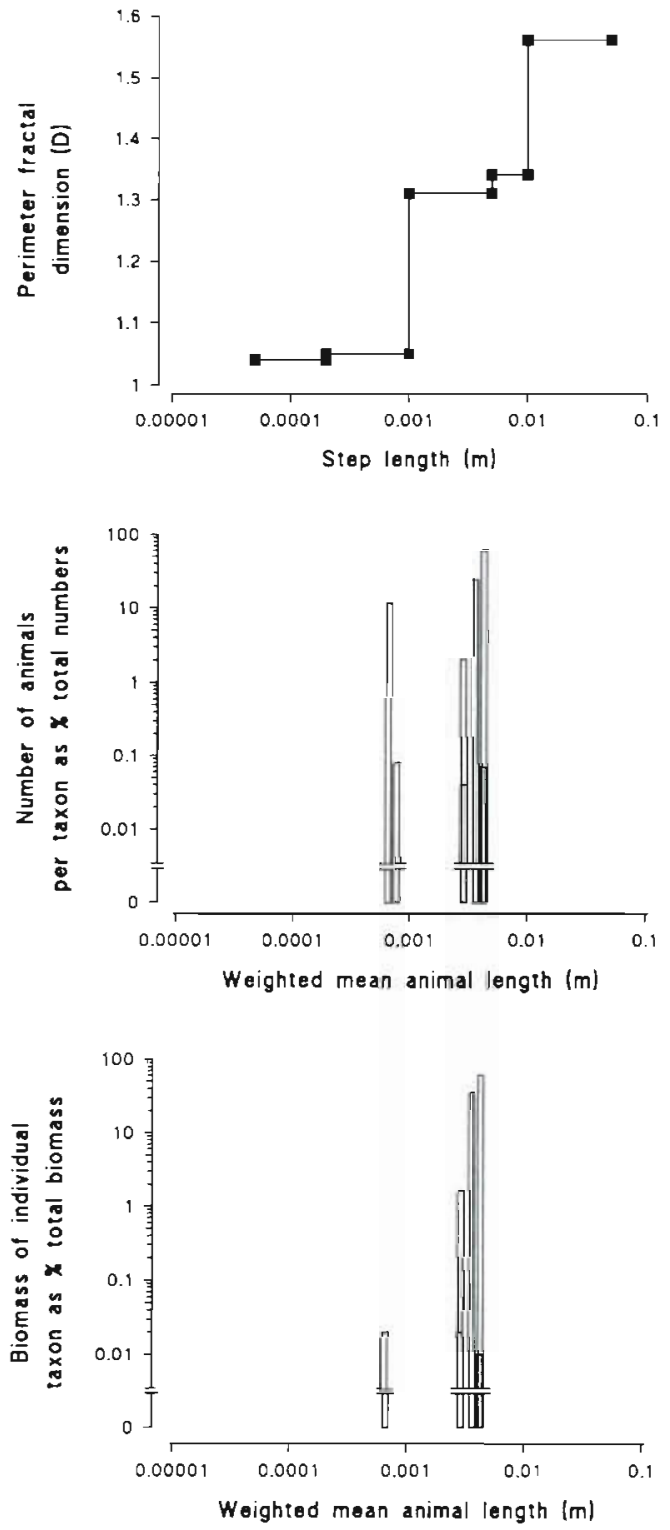

Fig. 5. Schizoseris condensata. Relationship between perimeter $D$ of plants measured at various scales (step lengths) in relation to epifaunal abundance and bromass. Each taxon is represented by a single histogram block

dimensional awareness). However, the importance of mobility to such perception is presently unstudied.

In the present study, harpacticoid copepods, the smallest animals recorded, would perceive Macrocystis or Palmaria as smooth, unless they happened to attach to the edges (which comprise a minute proportion of total surface area) of the fronds. In contrast, Schizoseris surfaces will appear complex, even for harpacticoid copepods. The situation for Desmarestia is less easy to predict because of the circular/elliptical cross section of the twig-like fronds. Perimeter (along frond) $D$ falls to 1 at step lengths of about $5 \mathrm{~mm}$, but
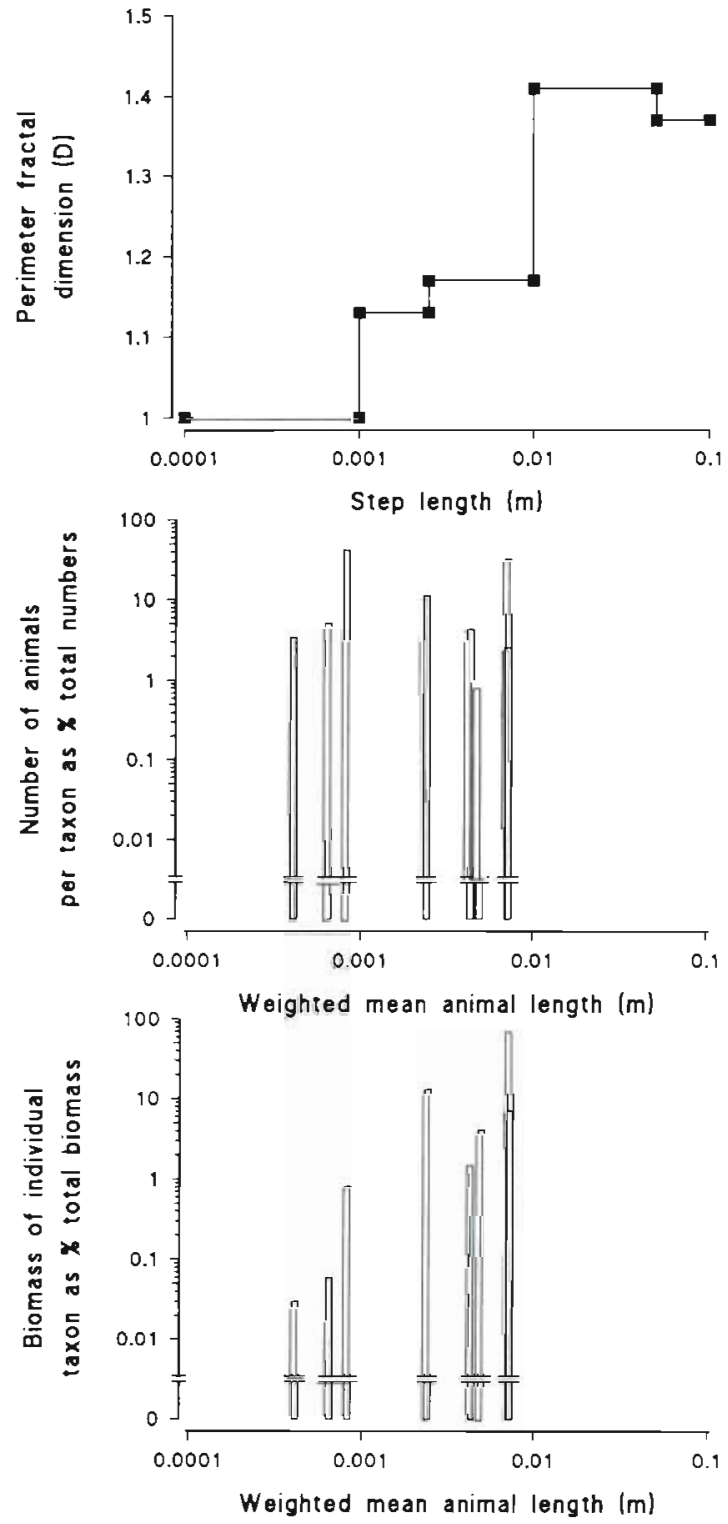

Fig. 6. Palmaria georgica, Relationship between perimeter $D$ of plants measured at various scales (step lengths) in relation to epifaunal abundance and biomass. Each taxon is represented by a single histogram block

the frond diameters are in the range $0.5-1.0 \mathrm{~mm}$. Within the mass of a Desmarestia plant it is likely that fronds will often touch one another, creating complexity which will impinge upon harpacticoids.

As far as individual epifaunal animals are concerned, Macrocystis is a simple, Euclidean structure. Complexity only emerges at scales of $50 \mathrm{~mm}$ and above. This contrasts with the general perception that Macrocystis beds are unusually complex, 3-dimensional habitats because the gas bladders ensure that the kelp reaches the surface at all stages of the tide (e.g. Barnes \& Hughes 1982). In fact, the complexity of 
Macrocystis does impact upon animals, but only larger ones not collectable in the present study. At Husvik it is known that fish (particularly Notothenia rossi) move through the kelp forest, preying on epifauna (Burchett 1983, Burchett et al. 1983); they are preyed upon in turn by South Georgia fur seals (Arctocephalus tropicalis gazella). Davenport (1995) has recently reported that kelp gulls (Larus dominicanus) at Husvik spend many hours each day feeding on epifauna of Macrocystis fronds floating at the surface, while moulting southern elephant seals (Mirounga leonina) are often seen resting in beds of basket kelp, sometimes for several days. All of these animals (ranging from about 0.3 to $6 \mathrm{~m}$ in body length, and from about 0.2 to $3500 \mathrm{~kg}$ ) are as much inhabitants of Macrocystis as the epifauna studied here - but they will perceive a complex 3 dimensional habitat with a $D$ of about 1.3 .

At even larger scales, Macrocystis beds have a perimeter $D$ of ca 1.4 , similar to some publıshed values for particularly convoluted coastlines (e.g. Pennycuik \& Kline 1986). South Georgia was recently heavily glaciated, and it seems probable that the high $D$ shown by Macrocystis beds at step lengths of $250-400 \mathrm{~m}$ is likely to be partly due to the nature of the coastline around which the beds are distributed.

A particularly important finding of the study concerned the relationship between algal fractal dimension and epifaunal size distribution. Both Schizoseris and Desmarestia exhibited complexity in 3 dimensions, exhibited high values of $D$ and showed epifaunal dominance (in terms of abundance as well as biomass) by relatively large animals (amphipods, isopods, bivalves), while the epifauna of Macrocystis and Palmaria, with values of $D$ ca 1 , was dominated by smaller species; this was particularly marked in the case of Macrocystis in which $95 \%$ of the epifaunal abundance consisted of harpacticoid copepods. This contrasts completely with findings for terrestrial plants in which high fractal dimension is associated with dominance by smaller forms (e.g. Morse et al. 1985). It also conflicts with the recent study of Gee \& Warwick (1994b) which demonstrated a similar (but much weaker) dominance of smaller forms (mainly harpacticoids) in intertidal algae. Our study, like that of Gee \& Warwick (1994b), relied considerably on sampling harpacticoid copepods. It may be argued (following Hicks 1980, 1985) that the $125 \mu \mathrm{m}$ sieving method employed might have overestimated harpacticoid abundance on flat algae such as Macrocystis, in comparison with a bushy species such as Schizoseris, because of morphological differences between copepod types (broad and flattened on flat-fronded algae, long and thin on fine algae). We believe that this is less of a problem on South Georgia than on the U.K. coasts studied by Hicks $(1980,1985)$ for 4 reasons: first, the harpacticoid fauna at South Georgia appeared relatively depauperate and there was no obvious species prevalence on individual macroalgal species; second, there was no significant size difference between copepods collected from different macroalgal species; third, there was no obvious preponderence of stouter harpacticoid species in the Macrocystis samples or slimmer ones in those collected from Schizoseris; fourth, none of the macroalgae studied were of the fine, filamentous type (e.g. Cladophora spp.) that features particularly slim harpacticoids.

Morse et al. (1985) worked in a terrestrial environment where the fluid surrounding the vegetation was air; Gee \& Warwick (1994a, b) studied macroalgae living in the harsh intertidal environment where they were also exposed to aerial influences. We believe that our divergent findings for the epifaunal composition of subtidal macroalgae probably reflect the very different physical characteristics of the fully aquatic medium. Rates of gaseous exchange are rarely diffusion limited in the terrestrial environment, but such limitation can be of profound significance in water (see Alexander 1971 for discussion). Complexity in algae is likely to result in low rates of water movement around the plant structure and hence thicker unstirred layers. Only animals capable of powerful ventilation of the respiratory' excretory surfaces would be able to take full advantage of complexity (though their presence would also benefit smaller epifaunal neighbours). Amphipods, isopods and bivalves all have such mechanisms; harpacticoid copepods are in the size range of animals which do not have specialized respiratory and circulatory systems, so rely on simple diffusion. We strongly suspect that the macroalgae studied by Gee \& Warwick (1994a, b) are also colonized by numbers of mobile amphipods - but only when the tide is in.

Another contributory factor to the unexpected size distribution of epifauna in Schizoseris and Desmarestia was the dominant presence of amphipods, particularly Orchomene zschaui. O. zschaui is a nocturnal scavenger (Moore 1994); during the day (when algal collections were made) they were effectively 'roosting' on the macroalgae, which provided support and refuge. Nocturnal algal sampling might thus have resulted in a very different epifaunal composition, with lower biomass and dominance of 'resident' species such as bivalves, Jassa sp. and isopods.

Acknowledgements. The authors thank the British Antarctic Survey (BAS) for logistic backup and access to facilities on South Georgia. They thank Commander A. Massey, officers and crew of HMS 'Newcastle' and Captain J. Cole, officers and crew of RRS 'James Clark Ross' for hospitality en route to and from South Georgla. J.D. thanks the Royal Society and the Transantarctic Association for travel funding that allowed him to work at Husvik. He is also grateful to Drs D. W. H. Walton and W. Block of BAS for inviting him to work at South 
Georgia. Mr H. MacAlister is thanked for his invaluable local experience and advice. Prof. P. G. Moore (UMBSM) and Dr J. Taylor (Natural History Museum) are thanked for identification of material. The authors are grateful for the constructive comments of 3 anonymous referees.

\section{LITERATURE CITED}

Alexander RMcN (1971) Size and shape. Edward Arnold Ltd, London

Barnes RSK, Hughes RN (1982) An introduction to marine ecology. Blackwell Scientific Publications, Oxford

Bradbury RH, Reichelt RE (1983) Fractal dimension of a coral reef at ecological scales. Mar Ecol Prog Ser 10:169-171

Bradbury RH, Reichelt RE, Green DG (1984) Fractals in ecology: methods and interpretation. Mar Ecol Prog Ser 14: 295-296

Burchett MS (1983) Food and feeding behaviour of Notothenia rossi from South Georgia. Br Antarct Surv Bull 61:45-51

Burchett MS, Sayers PJ, North AW, White MG (1983) Some biological aspects of the nearshore fish populations at South Georgia. Br Antarct Surv Bull 59:63-74

Burrough PA (1981) Fractal dimensions of landscapes and other environmental data. Nature 294:240-242

Davenport J (1995) Upwelling-generated plankton strandlines: important, predictable food sources for shore birds at Husvik, South Georgia. Mar Biol 123:207-217

Gee JM, Warwick RM (1994a) Metazoan community structure in relation to the fractal dimensions of marine macroalgae. Mar Ecol Prog Ser 103:141-150

Gee JM, Warwick RM (1994b) Body-size distribution in a marine metazoan community and the fractal dimensions of macroalgae. J Exp Mar Biol Ecol 178:247-259

Gunnarsson B (1992) Fractal dimension of plants and body size distribution in spiders. Funct Ecol 6:636-641

Hicks GR (1980) Structure of phytal harpacticoid copepod assemblages and the influence of habitat complexity and turbidity. J Exp Mar Biol Ecol 44:157-192

Hicks GR (1985) Meiofauna associated with rocky shore algae. In: Moore PG, Seed R (eds) The ecology of rocky coasts. Hodder \& Stoughton, London, p 36-56

This article was submitted to the editor
Jeffries M (1993) Invertebrate colonization of artificial pondweeds of differing fractal dimension. Oikos 67:142-148

John DM, Pugh PJA, Tittley I (1994) Observations on the benthic marine algal flora of South Georgia: a floristic and ecological analysis. Bull Br Nat Hist Mus Lond (Bot) 24 $101-114$

Lawton JH (1986) Surface availability and insect community structure: the effects of architecture and fractal dimension of plants. In: Juniper BE, Southwood TRE (eds) Insects and the plant surface. Edward Arnold, London, p 317-331

Mandlebrot BB (1967) How long is the coast of Britain? Statistical self-similarity and fractional dimension. Science 156:636-638

Mandlebrot BB (1977) Fractal form, chance and dimension. Freeman, San Francisco

Mark DM (1984) Fractal dimension of a coral reef at ecological scales: a discussion. Mar Ecol Prog Ser 14:293-294

Moore PG (1994) Observations on the behaviour of the scavenging lysianassoid Orchomene zschaui (Crustacea: Amphipoda) from South Georgia (South Atlantic). Mar Ecol Prog Ser 113:29-38

Morse DR, Lawton JH, Dodson MM, Williamson MH (1985) Fractal dimension of vegetation and the distribution of arthropod body lengths. Nature 314:731-733

Pennycuik CJ (1992) Newton rules biology. Oxford University Press, Oxford

Pennycuik CJ, Kline NC (1986) Units of measurement for fractal extent, applied to the coastal distribution of bald eagle nests in the Aleutian Islands, Alaska. Oecologia (Berl) 68:254-258

Richardson LF (1961) The problem of contiguity: an appendix of statistics of deadly quarrels. Gen Syst Yearbook 6 : $139-187$

Russ JC (1994) Fractal surfaces. Plenum Press, New York

Shorrocks B, Marsters J, Ward I, Evennett PJ (1991) The fractal dimension of lichens and the distribution of arthropod body lengths. Funct Ecol 5:457-460

Strange IJ (1992) A field guide to the wildlife of the Falkland Islands. HarperCollins Publishers, London

Womersley HBS (1954) The species of Macrocystis with special reference to those on southern Australian coasts. Univ Calif Pub Bot 27:109-132

Manuscript first received: October 17, 1995

Revised version accepted: December 11, 1995 